Meta

Journal des traducteurs

Translators' Journal

\title{
Gatekeeping Practices in Interpreted Social Service Encounters
}

\section{Sonja Pöllabauer}

Volume 57, numéro 1, mars 2012

La CIUTI, chef de file pour la promotion de l'employabilité et de la recherche

CIUTI: Leader in Advocating Employability and Research

URI : https://id.erudit.org/iderudit/1012750ar

DOI : https://doi.org/10.7202/1012750ar

Aller au sommaire du numéro

\section{Éditeur(s)}

Les Presses de l’Université de Montréal

ISSN

0026-0452 (imprimé)

1492-1421 (numérique)

Découvrir la revue

Citer cet article

Pöllabauer, S. (2012). Gatekeeping Practices in Interpreted Social Service

Encounters. Meta, 57(1), 213-234. https://doi.org/10.7202/1012750ar

\section{Résumé de l'article}

Le présent article fait état de résultats obtenus dans le cadre d'un projet consacré à l'interprétation dans les services sociaux et les structures d'aide sociale (Community Interpreting und Kommunikationsqualität im Sozial- und Gesundheitswesen[Interprétation communautaire et qualité de la communication dans les services sociaux et les établissements de santél), mis en oeuvre par une équipe interdisciplinaire, de 2007 à 2009. La pratique de l'interprétation auprès de deux structures de services sociaux et d'aide sociale municipales autrichiennes a été étudiée à partir d'entretiens approfondis et d'enregistrements de rencontres au cours desquelles l'interprète jouait un rôle authentique de médiateur. Après un aperçu de l'histoire de la théorie du contrôle d'accès et de l'application du concept aux recherches sur la traduction et l'interprétation, les résultats sont analysés à l'aide d'un modèle spécifique de contrôle d'accès proposé par Shoemaker et Vos en 2009. À la suite de ces auteurs, nous avons procédé à une analyse faisant appel à cinq niveaux distincts (la personne, les habitudes de communication, les organisations, les institutions sociales, le système social). Nous avons examiné les contrôles d'accès qui sont présents dans les habitudes de communication au sein de deux institutions et qui peuvent empêcher une compréhension ou un accès complets aux usagers non germanophones, ainsi que le rôle des interprètes en tant que contrôleurs d'accès.
Ce document est protégé par la loi sur le droit d'auteur. L'utilisation des services d'Érudit (y compris la reproduction) est assujettie à sa politique d'utilisation que vous pouvez consulter en ligne.

https://apropos.erudit.org/fr/usagers/politique-dutilisation/ 


\title{
Gatekeeping Practices in Interpreted Social Service Encounters
}

\author{
SONJA PÖLLABAUER \\ University of Graz, Graz, Austria \\ sonja.poellabauer@uni-graz.at
}

\section{RÉSUMÉ}

Le présent article fait état de résultats obtenus dans le cadre d'un projet consacré à l'interprétation dans les services sociaux et les structures d'aide sociale (Community Interpreting und Kommunikationsqualität im Sozial- und Gesundheitswesen [Interprétation communautaire et qualité de la communication dans les services sociaux et les établissements de santé]), mis en œuvre par une équipe interdisciplinaire, de 2007 à 2009. La pratique de l'interprétation auprès de deux structures de services sociaux et d'aide sociale municipales autrichiennes a été étudiée à partir d'entretiens approfondis et d'enregistrements de rencontres au cours desquelles l'interprète jouait un rôle authentique de médiateur. Après un aperçu de l'histoire de la théorie du contrôle d'accès et de l'application du concept aux recherches sur la traduction et l'interprétation, les résultats sont analysés à l'aide d'un modèle spécifique de contrôle d'accès proposé par Shoemaker et Vos en 2009. À la suite de ces auteurs, nous avons procédé à une analyse faisant appel à cinq niveaux distincts (la personne, les habitudes de communication, les organisations, les institutions sociales, le système social). Nous avons examiné les contrôles d'accès qui sont présents dans les habitudes de communication au sein de deux institutions et qui peuvent empêcher une compréhension ou un accès complets aux usagers non germanophones, ainsi que le rôle des interprètes en tant que contrôleurs d'accès.

\section{ABSTRACT}

This paper presents results gathered from a project implemented by an interdisciplinary project team between 2007 and 2009, which focused on interpreting in social service and welfare institutions (Community Interpreting und Kommunikationsqualität im Sozial- und Gesundheitswesen [Community Interpreting and Communication Quality in Social Service and Healthcare Institutions]). One of the aspects investigated by the project was the interpreting practice at two Austrian municipal social service and welfare institutions via in-depth interviews and recordings of authentic interpreter-mediated encounters. After a brief overview of the history of gatekeeping theory and the application of the gatekeeping concept in Translation and Interpreting Studies, some of the project results are analysed using one specific model of gatekeeping theory proposed by Shoemaker and Vos in 2009. Taking a leaf from this work, the analysis is based on five different levels, namely the individual level, communication routines, the organisation level, the social institutional level, and the social system level. The analysis investigates "gates" present in the communication routines at the two institutions and which may prevent non-German speaking clients from full access and understanding, as well as the role of interpreters as "gatekeepers."

\section{MOTS-CLÉS/KEYWORDS}

interprétation communautaire, organisation des services sociaux, contrôle d'accès, rôle de l'interprète, analyse du discours

community interpreting, social service settings, gatekeeping, interpreter role, discourse analysis 


\section{Introduction: Interpreting in Social Service and Welfare Settings}

Over the last decade, Interpreting Studies (IS) have been focusing extensively on Community Interpreting (CI) from different (theoretical and disciplinary) perspectives. Certain topics (for example, issues of role and interaction framework, interpreting ethics, discourse and turn organisation, quality, service-provision, training) and settings (for example, medical, legal) have been dealt with more extensively than others (Pöchhacker 2004: 162; Hale 2007: 200-201). Interestingly, though the classifiers "community" or "public service" are among the names given to the practice of interpreting outside conference and business settings ("Community Interpreting" or "Public Service Interpreting"), ${ }^{1}$ IS literature seems to lag behind in studies on interpreting in social service and welfare institutions while literature on interpreting in medical and legal settings (in that order) abounds.

A search in three translation/interpreting-specific databases (Translation Studies Bibliography, BITRA, LIDOC ${ }^{2}$ ) seems to support this initial assumption. ${ }^{3}$ Compared to interpreting in medical and legal settings, there is a lack of publications on interpreting in social service and welfare settings (see also Grbić and Pöllabauer 2008b: 321).

A qualitative analysis of the search results, based on titles, abstracts and superficial reading, provides an initial insight into the range of topics tackled and points out some general trends. Interestingly, the majority of the publications found in these databases are German publications focusing on public service institutions in German-speaking countries (Emmel 1992; Gaitanides 1997; Lin and Mutter 1998; Cerzniewski 2007; Tiğli 2007; Uebelacker 2007). In spite of the fact that English has been the predominant language in IS (Pöchhacker 2004: 196), we find a lower number of English publications focusing specifically on public services settings (Manyoni 1999; Wouters 1999; Jensen and Camayd-Freixas 2004; Lannoy and van Gucht 2006). ${ }^{4}$ Apart from German and English, a small number of publications has been written in Spanish (El Madkouri 2006) and French (Debevc-Moroz 1995), whereby it should be noted that the databases used show a predominance of English and German, and in the case of BITRA Spanish, and publications in languages other than that may not be accessible as easily via traditional search tools. Apart from empirical studies (Lannoy and van Gucht 2006; Cerzniewski 2007; Tiğli 2007; Uebelacker 2007), we also find a small number of handbooks (Shackman 1984; Rennie 1998) or recommendations (guidelines) on using interpreters (Glasser 1983; Corsellis 2003), as well as terminology-oriented publications (Blair, Campbell et al. 1990; Yallop 1992). The search also turned out publications focusing on how to work with interpreters in social work from the view of social workers (Baker 1981; Glasser 1983). What is also noticeable is that publications on sign language interpreting (SLI) (Roe and Roe 1991; Wilson 1996) tend to focus more extensively on "counselling services," while publications on spoken language interpreting seem to address a more diverse range of topics and settings.

In what follows I will present some results of a study which includes in-depth interviews and recordings of interpreter-mediated institutional encounters and which focuses on the practice of interpreting in social service and welfare settings in two specific Austrian institutions. The data presented are part of a larger corpus of interviews and recordings done at these two institutions by an interdisciplinary research project and will be discussed and analysed according to gatekeeping theory, focusing 
on "gates" in interpreting practice and the role of interpreters as "gatekeepers" in such encounters.

\section{2. “Gatekeeping” in Interpreting Studies}

"Gatekeeping" as a - at first sight rather abstract - concept has been repeatedly used in translation/interpreting (T/I) studies to describe the pivotal role(s) of translators/ interpreters, and sometimes also other participants, in T/I processes. What is common to many publications and has been a prevailing trend in different disciplines is that the concept itself is not tackled in depth but rather used as a metaphor or symbol for describing processes of access and/or exclusion, often without reference to the concept's theoretical origins and background (Barzilai-Nahon 2009: 14). In a comprehensive review of different approaches to gatekeeping theory, Barzilai-Nahon (2009: 19) maintains "that the concept is still used as a metaphor, symbol, or illustration mainly for the purpose of articulating ideas rather than as a stand-alone theoretical framework," which can also be said to be true for T/I studies. One case in point is, for instance, the Translation Frames: Gateways and Gatekeeping conference, ${ }^{5}$ organised in 2008 by the Centre for Translation and Intercultural Studies in Manchester, which even used the term "gatekeeping" in its title. The conference contributions were published in the CTIS Occasional papers, with only two publications referring to gatekeeping in the title (Almansi 2010; Monti 2010); interestingly none of these publications were included in the databases mentioned above.

In the T/I literature, the concept of gatekeeping is (less commonly) either mentioned in the publications' titles (Monnier 1995; Vuorinen 1997; Sarangi and Roberts 1999; Davidson 20096) or (more commonly) referred to in passing, mostly in the CI literature (Wadenjö 1998: 67-69; Tipton 2008: 7; Mason 2009: 60). Even if "gatekeeping" is part of a publication's title it is hardly ever used as an analytical tool used for investigating specific aspects of interpreting practice. Of the four publications with "gatekeeping"/"gatekeeper" in the title, only one provides information on the origins of the concept (Vuorinen 1997).

The concept has also been taken up by Translation Studies (TS), albeit, to my knowledge, less extensively than in IS. One of the first to have applied the concept of gatekeeping seems to have been Akio Fujii (Fujii 1988) in his study on news translation in Japan, in which he also provides a brief overview of the concept's history (though "gatekeeping" is not mentioned in the title). Almost ten years later, Vuorinen (1997) also applied the concept to news translation. What these two publications have in common and what makes them differ from others in IS, is that they provide more extensive information regarding the concept's theoretical underpinnings.

In CI research, Wadensjö (1998: 67-69), for instance, devotes one section of her pioneering study on interpreting in medical and immigration interviews to "gatekeepers" and describes them as "intermediaries between lay people and institutions" (Wadensjö 1998: 67). Her discussion of the concept is based on a much-quoted sociolinguistic publication on gatekeeping in academic interviews by Erickson and Shultz (1982):

As do all professionalized intermediaries, interpreters work at providing a particular service. Simultaneously, they - of necessity - exercise a certain control. Obviously, there is a potential conflict between the service and the control aspects, which sometimes 
surfaces in dilemmas reported in the literature on institutional communication. It largely remains to be investigated how this conflict is handled in institutional interpreter-mediated talk, where the gatekeeping is, in effect, doubled. (Wadensjö 1998: 68-69)

With her profound study of interpreter-mediated interactions, Wadensjö herself succeeded in addressing some of the open issues mentioned in the quote above. Davidson (2009), who was inspired by Wadensjö's approach, also took up the gatekeeping concept and concluded that in medical interviews, interpreters do not always act as patient "advocates," "[...] but rather, at least in part, as informational gatekeepers who keep the interview 'on track' and the physician on schedule” (Davidson 2009: 383).

\section{Gatekeeping Concept: Theoretical Underpinnings}

The gatekeeping concept can be traced back as far as the 1950s, when psychologist Lewin $(1947 ; 1951)$ first introduced the concept. It was later taken up by many different fields (Barzilai-Nahon 2009: 1). Some of the more prominent names in gatekeeping literature are White (1950), who focused on news selection processes and is regarded as one of the pioneers of gatekeeping research, Westley and MacLean (1957), and Shoemaker (1991) with one of the first reviews of the field (Barzilai-Nahon 2009: 2-3). It is not possible to provide a comprehensive overview of the development of gatekeeping concepts within the scope of this contribution. In this section, I will therefore suffice with providing a brief outline of the origins, before presenting one specific model (section 6), which will be used for analysing the data collected in the project presented here.

Publications on gatekeeping show a wide array of different topics and approaches, methods, research designs and epistemologies that are tackled by researchers with different disciplinary backgrounds. Gatekeeping has for instance been a topic in communication studies/journalism (the field of research where gatekeeping has been studied most extensively), law, political science, library and information science, management, public affairs, sociology (Barzilai-Nahon 2009: 1), and ethnolinguistics (Metoyer-Duran 1991). For a concept that has been present for more than 60 years now, the number of comprehensive reviews of the different gatekeeping theories however is surprisingly small (Barzilai-Nahon 2008: 1).

What is common to all of these studies is that they focus on the controlling, selection, filtering and brokering of decision-making processes and the flow of information/goods/services (Barzilai-Nahon 2009: 3-9) even though there does not seem to be a commonly accepted definition of what constitutes gatekeeping exactly (Chang 2004: 3). Some authors focus on the processes in general, others on the gatekeepers and the "gated" as well as individual factors (Barzilai-Nahon 2009: 3-4). Recent studies, especially in the fields of sociology, politicial science, have also started to view gatekeeping as a form of "agenda-setting" and a means of affecting "change" in society (Barzilai-Nahon 2009: 3, 29-30). In spite of the considerable number of different publications focusing on gatekeeping from different perspectives, there seems to be a lack of new, recent theories or at least new conceptualisations of gatekeeping (Barzilai-Nahon 2009: 40). For the purpose of this paper, I will define gatekeeping as follows, following Kurtz (1968: 66): Gatekeepers are persons who help people "gain access to resources needed to solve problems in one or more contexts." 
Gatekeeping as such is present in many everyday activities and can be observed in many different fields (Barzilai-Nahon 2009: 2). In his pioneering study of gatekeeping, Lewin (1951), for instance, focused on the food chain in households and how housewives functioned as gatekeepers who decided and controlled what came onto their tables (Chang 2004: 3). Erickson and Shultz's analysis of gatekeeping processes in academic counselling situations takes up gatekeeping (though without a detailed overview of the concept's epistemology) from a sociolinguistic perspective and seems to be the one publication that is primarily referred to in IS when it comes to gatekeeping processes (see Wadensjö 1998: 68). Erickson and Shultz view "counselors" as "institutional gatekeepers" who have "the responsibility and authority to make decisions about the social mobility" (Erickson and Shultz 1982: 4) of, in Erickson's and Shultz's case, students. In social service settings, it is firstly the service providers and institutional representatives (whether they are referred to as "social servants," "bureaucrats," "interviewers," "counsellors," or otherwise) who function as gatekeepers. When it comes to intercultural encounters and interpreters have to be involved, the interpreters may also function as gatekeepers, as Wadensjö points out (Wadensjö 1998: 69). For the purpose of this contribution I will focus only briefly on the service provider's role and some characteristics of institutional encounters (in our case in a social service and welfare context) before linking the gatekeeping concept with concrete data on interpreting situations. The analysis will be based upon the different levels of analysis suggested by Shoemaker and Vos (2009), who present a model, which may theoretically also be applied to different fields, i.e., interpreted encounters in our case.

\section{Institutional Encounters as Gatekeeping Encounters}

Most institutional encounters are gatekeeping encounters. The service providers are in a position to grant or withhold certain services, and their decision-making processes are based on specific (explicit and implicit) institutional routines and regulations. "Language" is a central element in gatekeeping: "Gatekeeping is largely accomplished through discourse processes" (Sarangi and Slembrouck 1996: 37). As Erickson and Shultz point out, there is a specific "logic" (Erickson and Shultz 1982: 20) to gatekeeping discourses. What is said in institutional encounters has to be in line with certain norms and conventions: "[...] bureaucrats function as gatekeepers of a social order" (Sarangi and Slembrouck 1996: 37). Rudvin also adeptly points out that in cross-cultural institutional encounters, even more than in intralingual encounters, "power in discourse" (2005: 165; italics in original) is one of the bureaucratic hurdles preventing "out-group members," i.e., marginalized groups, from being granted access to public services.

Applicants provide information (collected in face-to-face interviews or submitted in writing, for example, applicant forms) to obtain certain services and goods, material and/or immaterial. Information gathering follows very specific routines and step-by-step-processes (Sarangi and Slembrouck 1996: 38). The service providers have to process the information collected and then make their decisions (constrained by certain institutional requirements though sometimes with a certain leeway): "Information gathering in a bureaucratic procedure is geared towards establishing institutionally defined truths" (Sarangi and Slembrouk 1996: 48). Clients do not always know what is expected of them and may sometimes be considered by the 
service providers to be "uncooperative" (Sarangi and Slembrouk 1996: 44, 47), i.e., unwilling to provide all facts or the "truth." If applicants fail to fulfil their expected roles in an encounter, they may be "steered" into the desired direction by the bureaucrats (Sarangi and Slembrouk 1996: 44). Even if, as common today, institutions try to become more customer-oriented, clients still seem to have a "supplier" role, whereas the service providers occupy a "demander role" (Sarangi and Slembrouk 1996: 57-58). Sarangi and Slembrouck (1996: 87-90) also discuss some of the options the applicants have to react to, counter and sometimes even undermine these institutional gatekeeping routines. In interlingual situations (where an interpreter would be called in), clients may often not be aware of certain services available to them or rights they might be entitled to (Cambridge 2005: 143), and, as Cambridge points out, there is also the danger of misinterpreting culturally-determined factors (Cambridge 2005: 143).

\section{Project Outline: Community Interpreting in Social Service Settings}

The data presented in this article were collected in a project focusing on CI in social service settings. ${ }^{7}$ The project was implemented between 2007 and 2009 by an interdisciplinary research team (sociology, T/I studies, education and pedagogics, journalism and mediation). ${ }^{8}$ The project focused, on the one hand, on institutional encounters between social servants and non-German speaking clients in social service institutions, and, on the other hand, on the interpreting processes in such settings.

\subsection{Participating Institutions}

The study was conducted at two municipal social service and welfare institutions in the Austrian province of Styria. One was the housing department of the City of Graz (provincial capital), the other the municipal office ("Bürgerbüro") of Kapfenberg, a small town in upper Styria dealing with a wide range of different municipal services. Both institutions had agreed, after a lengthy negotiation and decision process, to participate in the project. Their main motivation for participation was that over the last few years, communication with non-German speaking clients had become increasingly "challenging," according to the employees' subjective assessment (Pöllabauer 2009: 3). The majority of these non-German speaking clients are migrants, specifically asylum applicants and Convention refugees. Active participation and involvement of the project partners was one of the concerns of the research team. The project was to be supported by the project partners and supposed to achieve a certain degree of "sustainability," i.e., it should also result in concrete measures being taken and not only remain "on paper." The results of the studies were discussed with the institutional representative and the management in feedback rounds and feedback was included in the final reports (Kukovetz and Sprung 2009; Pöllabauer 2009), which had to be submitted to the funding organisation.

\subsection{Methods and Data}

A combination of different methods was used: 1) The overall communication situation (mainly discussed from a sociological and educational approach) in the two 
chosen institutions was studied on the basis of in-depth interviews, with institutional staff providing the internal viewpoint, and staff/members of NGOS and migrant communities, representing the external viewpoint. In total, ten qualitative interviews were included in the analysis (coding and interpretation following Grounded Theory, computer-assisted analysis with MAXQDA) (Kukovetz and Sprung 2009: 4-6). 2) Authentic interpreted interactions were analysed mainly from the view of interpreting studies. Recordings were made at both the two institutions, transcribed (HIAT transcription system; computer-based with EXMARaLDA) and analysed. In total, six recordings were included in the analysis. Apart from one encounter, where the client spoke Turkish, the language combination was German-Chechen ${ }^{10,11}$ (for details see Pöllabauer 2009: 3-8).

\section{Gatekeeping Reality: A Glimpse into Interpreting Practice}

Shoemaker and Vos (2009: 31) suggest an analysis of gatekeeping processes at five different levels: 1) the individual level, 2) the communication routines level, 3) the organization level, 4) the social institutional level, and 5) the social system level. In what follows I will make use of that typology (though not necessarily in the same order) and present data on interpreting organisation and authentic interpreted encounters in the two institutions participating in the study.

A full summary of the data on interpreter practice can be found in Kukovetz and Sprung (2009), who designed and conducted the in-depth interviews and were responsible for data interpretation. Questions focusing on interpreter demand, interpreting practice, and related problems were drafted in cooperation with the translation scholars in the project team. Data interpretation was part of a team process as well. A full analysis of the recorded interpreted encounters can be found in Pöllabauer (2009). Some of the data have already been presented in another (German) contribution, though with a different focus, discussing translation culture at these two institutions (Pöllabauer 2010) ${ }^{12}$.

Before focusing on the individual level of analysis, which seeks to analyse characteristics of the individuals involved in gatekeeping processes (gatekeepers) and/or specific "units of communication content" (Shoemaker and Vos 2009: 31) and is the first level of Shoemaker's and Vos's (2009) analytical model, I will discuss different aspects under the remaining four levels of analysis as these, in my view, may help to provide a clearer overview of some general trends, which are often typical of CI encounters (in Austria as well as other countries) and which can be found at the two institutions under study.

Due to the scope of this contribution, I will only use some of the core elements of Shoemaker's and Vos's approach which appear adequate for discussing interpreting processes; the concept itself is, of course, far more complex and elaborate than might appear from this brief excursion into gatekeeping theory. Though the approach chosen by Shoemaker and Vos focuses primarily on selection and communication in mass media institutions, it is explicitly said to be "intended to address other types of content as well" (Shoemaker and Vos 2009: 6): "It also provides a structure for the study of processes other than selection, such as how content is shaped, structured positioned, and timed" (Shoemaker and Vos 2009: 11), and thus may be applied to CI in my view. 


\subsection{Communication routines and interpreting practice at social service institutions}

In the centre of this first level of analyses are routines and practices that are "emblematic of the field" (Shoemaker and Vos 2009: 31) rather than of concrete individuals and/or organizations. The movement of certain "items" (of information) through a "gate" is, to a large extent, also controlled by a specific set of rules, which Shoemaker and Vos (2009: 51) refer to as "communication routines": "Even when an individual appears to be a gatekeeper, we must ask about the extent to which the individual is merely carrying out a set of routine procedures." (Shoemaker and Vos 2009: 51). Within organizations, specific routines/practices develop which help the institutional representatives to fulfil their tasks, and may be both functional and efficient because "they make manageable the unmanageable" (Shoemaker and Vos 2009: 57). Such practices may be imposed by the management (Shoemaker and Vos 2009: 58) or simply develop on their own. With the socialisation of gatekeepers into a specific institution they also "learn" the explicit and implicit routines and practices favoured within a certain institution (Shoemaker and Vos 2009: 60). The advantage here, for example, is that routines may make work faster and consequently cheaper (Shoemaker and Vos 2009: 60). When these theoretical constructs are applied to the data under study we find a set of routines and practices, which are common to both institutions investigated.

"Language problems" are viewed as a challenge (not to say problem) in both institutions, next to other factors which make communication with "foreigners" and counselling routines challenging. Among these are lack of resources, lack of time, socio-political context and emotional factors ("difficult" clients) (Kukovetz and Sprung 2009: 12-14). Language problems are often solved through the use of interpreters (in both institutions about $20-30 \%$ of all client contacts are interpretermediated encounters) (Kukovetz and Sprung 2009: 8, 22). More often than not, these interpreters are amateur interpreters (Kukovetz and Sprung 2009: 9, 22). Both institutions sometimes also use children as interpreters, at least for topics which are considered "less difficult" (Kukovetz and Sprung 2009: 9, 24), though interviewees showed a certain degree of awareness that the use of children as interpreters may be problematic. Interestingly, it was not the content of specific encounters that was considered difficult, but other aspects that were said to be disturbing by the interviewees, i.e., the fact that interpreting may be a burden (also emotional) on children, that children should be in school and not "working" as interpreters in social service institutions, that children are, in their experience, sometimes reprimanded by their parents if they think their children have misinterpreted information (Kukovetz and Sprung 2009: 24).

Apart from using interpreters as a solution for "communication problems" we also find other makeshift solutions, such as the use of written material and the use of English as a lingua franca (Kukovetz and Sprung 2009: 18). This practice has been described by one of the interviewees of the housing department "Well you somehow have to make yourself understood with your hands or feet" (Kukovetz and Sprung 2009: 18; my translation). This situation is still very common for CI encounters, though internationally the situation differs. Some countries have "pioneer" status when it comes to professionalization of interpreting services, others have achieved a 
certain degree of professionalization/institutionalisation in some sectors, such as legal and medicals settings, whereas others still are lagging behind (Ozolins 2000: 22-24). For Austria, we find a limited degree of professionalization in court interpreting (Kadrić 2009), the medical (Pöchhacker 2007: 123) and other sectors are nonetheless widely underdeveloped. In the face of previous studies (Pöchhacker 2000a), these first results of the project there did not come as a surprise to the project team.

Linking these results with gatekeeping theory, we can sum up that the common practice of using untrained interpreters (or other makeshift ways of making oneself understood) can be said to be one of the major "gates" for non-German speaking clients of social service institutions which puts them at a clear disadvantage when compared to German-speaking clients. Assumed language proficiency cannot automatically be equalled with interpreting competence as has been pointed out in several studies (Bahadir 2010: 14). The use of children as interpreters may be considered highly hazardous (Pöchhacker 2000b) and the use of natural interpreters may sometimes work out (Angelelli 2004) but will more often than not be less efficient and cost-beneficial as assumed by the service providers. These "gates" can also be said to have been sanctioned and become institutionalised in the two institutions under study.

The management is aware of communication problems and how these are usually solved. Due to lack of resources, however, they have to continue to resort to ad-hoc measures as described above. The in-depth interviews with institutional representatives showed, however, that most interviewees were (at least partly) aware of the shortcomings of unprofessional ad-hoc solutions (Kukovetz and Sprung 2009: 11). In the face of such routines and practices it may be assumed that not all information gets through the gate and is received and understood by the foreign-speaking clients as is born out, for instance, by the analysis of the recorded interpreted encounters (see below and also Pöllabauer 2009).

\subsection{Organizational level of analysis}

Under the label "organizational level of analysis" Shoemaker and Vos (2009: 32) investigate specific characteristics that differ within different institutions. Organisational size, organisational socialisation, shared values and "groupthink," issues of gender, etc. may have an influence on communication practices (Shoemaker and Vos 2009: 62-75).

Apart from some common characteristics discussed above, we also find a number of differences in the two institutions under study. The "Bürgerbüro," for instance, has established what they call an "interpreting pool" as part of a project funded by the European Refugee Fund several years back. Interpreters in that pool, which has officially been named "Pool der DolmetscherInnen und VermittlerInnen" (Pool of Interpreters and Mediators), have received a certain degree of training and tend to view themselves as "trained" interpreters. A closer look at the training concept, however, shows that their training did not include interpreting-specific elements or language-specific training and was also limited in duration (Kukovetz and Sprung 2009: 9-11). The staff members interviewed within the project felt that the pool was a "model project" (Kukovetz and Sprung 2009: 9). In an additional discussion round it turned out, however, that they nonetheless often had the feeling that interpreters 
sometimes intervened on behalf of the clients and did not remain impartial (Kukovetz and Sprung 2009: 11). This fact may be seen as another "gate" for communication: The assumption that interpreters are trained, even though they have not in fact received that degree and kind of training deemed adequate for interpreting by training institutions (Ertl and Pöllabauer 2010: 180-181) may give staff members a false impression of what to expect from their interpreters and what their limits are. The fact that interpreters from the interpreter pool are also often called upon as "mediators" in conflicts (not only for interpreting purposes) can also be viewed as a "gate" prohibiting the full and transparent flow of information. Mediators may even have a very different role from interpreters. Due to lack of training (especially with respect to professional role, interpreting ethics, etc.), it cannot be assumed that the interpreters of the Kapfenberg pool will be aware of conflicting role profiles.

What also differs in both institutions is the level of problem awareness and the measures taken, i.e., increasing interpreting demand and solutions. The "Bürgerbüro" established its pool (with all the drawbacks as discussed above) years ago and also participated in a more extensive follow-up project in which results of the projects were addressed and taken up (including a more comprehensive awareness-raising towards the role of interpreters) (Pöllabauer and Zettelbauer 2009: 47-48). The housing department has also shown a certain awareness of problems, but no concrete measures have been taken so far, even though the interviewed staff members felt that a "pool of interpreters" would be "optimal" though not "realistically feasible" (Kukovetz and Sprung 2009: 33). Due to lack of time, follow-up measures were limited to the translation of information brochures.

One of the most problematic "gates" within the communication routines of the housing department, however, is the use of completely untrained lay interpreters, often also friends or relatives accompanying the clients (Kukovetz and Sprung 2009: 8-9). Compared to the "Bürgerbüro," this system shows a higher degree of inefficiency as clients are sometimes able to obtain information only after several attempts of contact with the office, which may make a simple application for a specific service (for example, housing benefits) a complicated process involving different inefficient steps: 1) get form, 2) return with form - filled out wrongly, 3) take new form and return with newly filled-in form, 4) return with interpreter for meeting with institutional representative (Kukovetz and Sprung 2009: 18). This is clearly a very complicated process and an obstacle preventing clients from getting quick access to information. One difference in communicative practice between the two institutions is that the housing department mainly relies on their clients to "bring" their own "interpreters," while the Bürgerbüro usually "provides" interpreters from its pool.

Another serious "gate" that can be seen from the interviews is the Germanlanguage proficiency of some interpreters. NGO employees interviewed to obtain an additional external perspective (Kukovetz and Sprung 2009: 5) often pointed out that the interpreter's German language competence often did not seem to be much higher than the clients' German language skills (Kukovetz and Sprung 2009: 24). Though this problem has not been mentioned by the Bürgerbüro interviewees, the analysis of the transcripts proved that in some instances the "trained" interpreters' German language proficiency was highly deficient (Pöllabauer 2009: 37). 


\subsection{Social institutional level}

The social institutional level focuses on external forces/agents who may have an influence on specific practices/routines, for example, interest groups, political forces (for example, governments) (Shoemaker and Vos 2009: 32). With respect to the Austrian context, this category can be dealt with very briefly. Similarly to many other European countries, no government initiatives (or initiates by major stakeholders and decisionmakers) have focused on improving (or at least addressing) the interpreting practice in social service institutions (Ozolins 2010). This lack of awareness of a highly deficient situation can be viewed as another gate in the process of providing a certain group of clients with fair and equal access. Certain recent developments at EU level, for example, projects focusing in the professionalization of legal interpreting such as the AGIS projects (see EULITA 2011 ${ }^{13}$ ), or the Special Interest Group on Translation and Interpreting for Public Services (SIGTIPS) of the European Language Council, ${ }^{14}$ aim at effecting a change. It remains yet to be seen, however, how exactly such initiatives will be implemented and continued in the long term.

As regards interest groups, some NGOs, which usually are the only lobby migrants have in a host country, have become active and offer in-house training for their interpreters (Wedam 2009: 186-187) to be able to meet their own interpreting needs. Interpreter training institutes are another interest group, which would be in a position to at least address the drawbacks of current suboptimum interpreting practices. In Austria, such training institutes are primarily the Department of Translation Studies at Graz University and the Centre for Translation Studies at Vienna University. In both Graz and Vienna, CI has been a focus of research and results of empirical studies have been distributed via academic but also non-academic channels. One serious "gate" for the professionalizing of interpreting practice in social service settings, however, is the lack of comprehensive training measures for CI (Ertl and Pöllabauer 2009) which is part of a vicious circle: no training programmes - no trained interpreters - use of lay interpreters - little awareness as regards professional role - yet difficult to change due to lack of training initiatives and of recognition of the problem among institutional representatives.

Shoemaker and Vos (2009: 76) also mention "market mechanisms" as one of the forces which may be part of gatekeeping processes, a fact which also holds true for the Austrian context as even though there is a high demand for CI in different sectors, there is only a small "market" for professional interpreters. The market has been dominated by untrained interpreters, who often receive no payment for their services (Ozolins 2010: 210). CI is often still considered a low-prestige affair with many professionals not wanting to be involved (Gross-Dinter 2009). Recently however we can trace a slow but gradual improvement: CI has started to become a topic in interpreter training and has also been taken up in EU projects (Ertl and Pöllabauer 2010: 168).

\subsection{Social system level}

This level of analysis seeks to address factors of the social system, which govern the practices of an institution (for example, political, economic factors, ideology, culture) (Shoemaker and Vos 2009: 32) and determine the structure and content of a message (Shoemaker and Vos 2009: 97). This category is very complex and could be dealt with 
in much depth. Due the scope of this paper, however, I will suffice with pointing out some preliminary considerations.

Equal opportunities and the right to make one's own decisions are (theoretically) fundamental pillars of the social system in democratic countries. What appears clearcut on paper, however, cannot always be implemented in practice. How countries deal with the increasing demand for interpreting in social service settings is a case in point, specifically with respect to the context under study. As has already been mentioned in the previous section, interpreting needs are often met with ad-hoc solutions which cannot always provide the necessary level of quality. We do not yet find much awareness and acceptance of the language needs of a marginalised group, in this case migrants, within Austrian society, and so far, there has been a lack of initiatives trying to remedy this suboptimal situation. The reasons for this are, of course, of a financial nature (the establishment of full-scale, professional interpreting services costs money). There may, however also be an ideological element in the perpetuation of the status quo. According to Shoemaker and Vos (2009: 103), ideological constructs may also determine the processes of selecting and structuring content. Ideology is a parameter which shapes individual actor's actions and should also be dealt with at an individual level. Ideology, however, also makes itself present at a more abstract social system level when it comes to certain "worldviews" a member of a society may have and the consequences these may entail: "Hence, the agency of gatekeepers is bound by the ideology that they have internalized through enculturation and education." (Shoemaker and Vos 2009: 103).

One ideologically determined factor is the overall attitude of a majority within a society towards the acceptance and integration of foreigners. For Austria (as for other countries, see for example, Ozolins 2010: 197), it still holds true that negative attitudes towards "foreigners" prevail within certain strata of the population. These negative feelings have been exploited extensively (and successfully as the results of recent elections show) over the last few years by right-wing political parties. Migration/integration is a very sensitive topic and many politicians seem to be afraid to take up the topic within a wider perspective and base discussions on facts instead of unfounded fears, probably fearing that these might cost them voters. Such ideological constraints are clearly a "gate" that is very difficult to pass.

"Culture" is another construct which, according to Shoemaker and Vos (2009: 104), shapes the flow of information: "The logic of culture's influence on news content is that gatekeepers adopt meaning systems from their cultural environment." (Shoemaker and Vos 2009: 105). This of course does not only apply to "news" content but to content in general. In CI especially, "culture" has been a much-discussed subject (Rudvin 2006) and "gate" in interpreter-mediated encounters. The concept of "culture" as such is far too complex to be discussed here in depth. I will therefore only point out some of the issues related to culture which are often tackled in IS. In interpreter-mediated situations the communicative parties often have diverse cultural backgrounds, with different degrees of education (or lack thereof and even illiteracy), worldviews and ideologies (differing considerably in people having been enculturated within a democracy or within a dictatorship), different norms and values (also regarding the roles of men/women), etc. Interpreters may belong to either culture (or even a third in the case of languages where interpreters are used for a lingua franca spoken by the interpreter and foreign-speaking client, for example, Russian with many 
Chechen-speaking clients in Austria). This superficial insight into some aspects related to culture may at least help to show that, in CI situations, issues of culture are far too complex to be able to grasp which cultural parameters may have influenced individual gatekeeper's (for example, interpreters) decisions to include, change or leave out certain pieces of information.

\subsection{Individual level: Moving into a new flat}

At the level of the individual I will take a closer at look at one specific encounter, focusing on how the interpreter in that example construed his role as interpreter and in which way "content" is passed in that specific encounter. Shoemaker and Vos describe gatekeeeping as "similar to the consumer decision-making process because gatekeepers are consumers, producers, and distributors of messages." (Shoemaker and Vos 2009: 39) and "decision rules" are sometimes imposed by the organisation, but are not always executed similarly on an individual level (Shoemaker and Vos 2009: 39). Even though we do not have access to the demographic characteristics of the interpreters under study (no pre- or post-encounter interviews with the interpreters were conducted and no demographic data were collected except for nationality, language, relation to client, and training background) the transcript nonetheless allows us to draw some general conclusions as to the role conceptions of the interpreters in that specific example. "Professional role conception" is a major factor of analysis on the individual level according to Shoemaker and Vos (2009: 47): "The gatekeeper's ideas about what his or her job entails can also affect gatekeeping choices."

The examples presented in what follows are taken from one of the transcripts of the corpus of recorded authentic interviews collected within the project. The situation involves three speakers: The institutional representative (a female staff member of housing department), the client (Turkish-speaking elderly citizen), and the interpreter (the client's son-in-law). The client is an elderly Turkish man living in Austria who had already taken a look at a flat which would be adequate for his family's needs but is in need of renovation. He wants to see the flat again, together with his wife, to be able to decide whether to take out a rental agreement or not. In that specific encounter he is given information on the following aspects: how to make a new appointment to be shown the flat again, who is responsible for the renovation work, how to apply for housing benefits, and which information to submit if he decides to rent the flat.

A close look at the transcript reveals that there are several gates in the encounter where information is filtered, appears to have been lost or where it is not clear whether specific bits of information have passed the gate. The most obvious characteristic of that specific encounter is that the interpreter obviously does not regard himself as "interpreter" in the sense that, for instance, professional codes of ethics for interpreters would define an interpreter's role (i.e., as a passive, impartial language broker): he does not interpret what is said over longer passages but instead enters into a conversation with the institutional representative, asking her for additional information - though without informing the client. As he is the client's son-in-law it may be assumed that he acts in the client's interests (though this must not necessarily be true) and upon his instructions. The fact that the client does not object to the interpreter's intervention seems to support this assumption. 
Overall, the interpreter assumes a very active, interventionist role. He seems to view himself not as an interpreter as such, but rather as a spokesperson for his fatherin-law. His role as interpreter seems to emerge out of "cultural certification" (Lu 2007: 110), meaning that in communities with conventions and cultural norms different than in the mainstream community, certain individuals are legitimated "as having the authority in transmitting certain information." In our case, it's the interpreter's presumed language skills legitimising him for his role as interpreter. We find several instances in the transcript, though, where he does not translate information for the client, asks for additional information or clarification and adds new content. It is not clear how much of what is said is understood by the client. After several turns it becomes obvious that the client has at least a basic knowledge of German and seems to be able to follow at least parts of the conversation (for example, line 5: Ja, schon./ Well, yes.; line 9: kaputt/broken), his overall German language proficiency seems to be very passive though.

In the following example we can see that the client seems to be able to follow what is said. In line no. 6 he attempts to answer in German, but then switches to Turkish. The interpreter then delivers an "expanded rendition" (Wadensjö 1998: 107) and adds new information (The flat needs to be renovated) to the original question (When can we move in?). This new bit of information then dominates the next few turns. Such instances of codeswitching as in this example are sometimes a typical element of interpreted encounters. When analysing medical interviews, Meyer (2009), for instance, found that clients who speak several languages repeatedly switch between these and are quite flexible in their choice of language, depending on their proficiency in the respective languages. In example (1), the client (C) switches from German to Turkish (Ne zaman bir șey...):

\begin{tabular}{|l|l|l|l|l|}
\hline IR & $\begin{array}{l}\text { die Wohnung? } \\
\text { the flat? }\end{array}$ & $\begin{array}{l}\text { Jo. Und die passt? } \\
\text { Yes. And it is OK? }\end{array}$ & \\
\hline Int & & $\begin{array}{l}\text { Ja. } \\
\text { Yes. }\end{array}$ & & \\
\hline C & & & & $\begin{array}{l}\text { Jo, pass (die Wohnung). Ne zaman } \\
\text { bir sey } \\
\text { Yes, is OK (the flat). }\end{array}$ \\
\hline
\end{tabular}

(Wohnungsamt Transcript 1 , line 6$)^{15}$

Apart from such passages where brief remarks or also feedback behaviour of the client suggest that he did at least grasp some of the content passed between the institutional representative and the client, several utterances are not translated and acknowledged by the client. In these instances it remains entirely unclear what and how much the client understands. He seems to rely completely on his son-in-law which is understandable but also potentially hazardous. As Metoyer-Durand (1991: 326) points out, "gatekeepers who guard the gate" and protect their own in-group from "outside influences pose a special challenge to information providers." A brief analysis of turn-taking in the example under study shows that the institutional representative has 32 turns in total, the client 16, and the interpreter 36 . Without going into detail, these basic statistics show that the interpreter is an active agent in the encounter, even more active than the client. The interpreter converses with the 
institutional representative for longer stretches during the entire encounter. Sometimes the client adds additional information to what the interpreter has said. The following example is one of the few passages, and the first instance of the encounter under study, where the interpreter provides a "close rendition" (Wadensjö 1998: 107).

(2)

\begin{tabular}{|l|l|l|}
\hline IR & $\begin{array}{l}\text { möchten's noch mal anschaun. Soll ich's reservieren? } \\
\text { you would like to see it again. Shall I make a reservation? }\end{array}$ & \\
\hline Int & & $\begin{array}{l}\text { Kamma/Sana reservieren } \\
\text { Can we/Should she make a }\end{array}$ \\
\hline
\end{tabular}

\begin{tabular}{|l|l|l|l|}
\hline Int & $\begin{array}{l}\text { yapsm? } \\
\text { reservation? }\end{array}$ & $\begin{array}{l}\text { Ja, kannst du schon } \\
\text { Yes, you can }\end{array}$ \\
\hline C & & $\begin{array}{l}\text { Reservieren ama/öbür evden çıacam. } \\
\text { Make a reservation/I have to move out of my flat. }\end{array}$ & \\
\hline
\end{tabular}

(Wohnungsamt Transcript 1, lines 20-21) ${ }^{16}$

What we also find in this transcript is what had already been pointed out by one of the interviewees (see above): the interpreter's language competence in German is rather low and full of formulaic expressions; he also does not seem to be aware of or master politeness conventions (for example, his use of du in line 21 when addressing the housing department representative, which is an informal way of addressing speakers and would usually not be used in institutional encounters). He manages to make himself understood for the relatively simple content discussed in this example. It remains unclear however how he would be able to cope with more complex topics.

One instance is especially interesting, namely when the client suddenly joins the communication in German. The interpreter then comments/corrects the client's utterance (No, no, no.) and is again corrected by the client (Yes, Mr. K.).

(3)

\begin{tabular}{|l|l|l|}
\hline IR. & $\begin{array}{l}\text { Hausverwalterin. } \\
\text { property manager. }\end{array}$ & \\
\hline C. & & $\begin{array}{l}\text { Aba, gestern vorgestern isch hab/ich anrufen die Nummer. Ein } \\
\text { But yesterday, the day before yesterday I have/I call the number. A }\end{array}$ \\
\hline
\end{tabular}

\begin{tabular}{|l|l|l|l|}
\hline IR. & & $\begin{array}{l}\text { Jo. Aha, der Herr K. } \\
\text { Yes. Ah, Mr. K. }\end{array}$ & \\
\hline Int. & & $\begin{array}{l}\text { Na, na, na. } \\
\text { No, no, no. }\end{array}$ & \\
\hline C. & $\begin{array}{l}\text { Kollege kommt (von hier). } \\
\text { colleague comes (from here). }\end{array}$ & & $\begin{array}{l}\text { Ja, Herr K. } \\
\text { Yes, Mr. K. }\end{array}$ \\
\hline
\end{tabular}

(Wohnungsamt Transcript 1, lines 30-31)

In one rather complex exchange of turns the institutional representative provides information about housing benefits in general and the modalities for calculating the amount the client's family would be entitled to. The institutional representative's information about the standard procedure is not interpreted (due to lack of understanding?). The client signals with a brief comment that he understands what is discussed $(A h$, that.). The interpreter then starts a new sentence but then stops again 
and after a few phrases simply repeats what has already been said, before he embarks upon a new question (Can we already do the new rental agreement?). It remains entirely unclear what is understood exactly by whom (client, interpreter). Bits of information (detailed procedure, background information) seem to get lost. A comment uttered by the interpreter in line no. 70 seems to indicate that he did not fully grasp what had been said before and merely filtered what appears important to him - namely that his father in law may rent the flat if he wants to.

(4)

\begin{tabular}{|l|l|l|}
\hline IR. & $\begin{array}{l}\text { einen Brief, wo drin steht, dass Sie diese Wohnung bekommen. } \\
\text { a letter, saying that you get this flat. }\end{array}$ & $\begin{array}{l}\text { Jo. } \\
\text { Yes. }\end{array}$ \\
\hline Int. & & $\begin{array}{l}\text { Bekommen, ja okay, } \\
\text { Get, yes, okay, }\end{array}$ \\
\hline
\end{tabular}

\begin{tabular}{|l|l|l|}
\hline IR. & & $\begin{array}{l}\text { Und wie gsagt, wenn Sie nächste Woche/ wenn Sie nächste Woche noch } \\
\text { And as I said, if you can come next week/ if you come again next week }\end{array}$ \\
\hline Int. & $\begin{array}{l}\text { supa. } \\
\text { great. }\end{array}$ & \\
\hline
\end{tabular}

(Wohnungsamt Transcript 1, lines 70-71)

\section{Conclusion}

This paper discussed some results of an interdisciplinary research project on interpreting in social service and welfare institutions from the view of gatekeeping theory. Shoemaker's and Vos's (2009) gatekeeping concept served as the basis for the analysis of the data collected within the project. What became very clear is that the interpreting practice at the two municipal social service institutions under study is governed by different constraints. We find several "gates" in these encounters, which make (or may make) access to services and/or information more difficult for nonmother-tongue clients than probably for German-speaking clients. One of these "gates" is the lack of high-quality interpreter provision: communication problems are solved through makeshift solutions (for example, use of translated written material, nonverbal communication, ad-hoc interpreting) which may put clients at a disadvantage compared to German-speaking clients. If interpreters are called in, these are often amateur interpreters. Some regard themselves as "trained" interpreters though they have enjoyed, in fact, very little or not interpreting-specific training. In one of the two institutions under study an "interpreter pool" has been established. The criteria for being admitted into the pool are very vague though and the role of the interpreters in the pool is not clearly defined; they have to serve as "mediators" in conflict situations but should at the same time act as neutral language brokers. Another gate that could be established in the data under study is the interpreters' lack of proficiency in German. Examples of one specific interpreter-mediated encounter also prove what other authors have already suggested: interpreters in such real-life encounters seem to have a much wider view of their tasks and adopt a much more interventionist approach than would be deemed adequate by many interpreting trainers or codes of conduct. The overall interpreting practice as it could be studied at these two institutions is emblematic for many community interpreting situations, in Austria, as well as other European countries: there is still no consensus as to what is 
and what can be expected from an interpreter in different settings. It has to be noted however, that recently, community interpreting has been taken up to a greater extent by university-level training institutions (for example, the CIUTI Symposium Community Interpreting: Training \& Research at University Level held in 2009 in Graz) and also at EU level (for example, the Special Interest Group on Translation and Interpreting for Public Services initiated in 2010 by the European Languages Council) which will hopefully provide new impetus for a critical discussion of diverse issues of community interpreting.

By way of conclusion it can also be noted that gatekeeping theory (with its many different theoretical approaches and models) can be used as a suitable analytical tool for the analysis of interpreting-specific data. Within the scope of this contribution it was only possible to address some basic issues. It might prove worthwhile however to focus in more depth on gatekeeping, and apply other gatekeeping approaches to CI research.

\section{NOTES}

1. The literature provides us with different namesakes for what has been called $\mathrm{CI}$ in this paper; the different labels (for example, Public Service Interpreting, Dialogue Interpreting, Cultural Interpreting, etc.) are not always synonyms but may carry different meanings depending on the geographic and cultural context they are used in (see Hale 2007: 28).

2. The Benjamins Translation Studies Bibliography is a commercial database with currently more than 20,00 records. BITRA is an online (free) Bibliography of Translation and Interpreting provided by the Universidad de Alicante (Dep. of Translation and Interpreting) with currently more than 48,000 entries. LIDOC is a database of translation and interpreting literature kept by the Department of Translation Studies at the University of Graz with currently more than 30,000 entries (limited access).

3. Due to the limited scope and orientation of this paper no full-scale scientometric analysis was conducted (see, for example, Grbić and Pöllabauer 2008a). For problems regarding the use and representativity of databases in T/I studies, see Grbić and Pöllabauer (2008a: 92-93).

4. This may only partly be explained through the inclusion of LIDOC as one of the research platforms used for this overview. LIDOC is maintained by the Graz Department of Translation Studies where CI has been one of the Department's dominant strands of research. The results found via the other two databases point into the same direction.

5. Translation Frames: Gateways and Gatekeeping, Centre for Translation and Intercultural Studies, University of Manchester, 30 June - 1 July 2008. Visited on 22 June 2011, <http://www.llc.manchester.ac.uk/ctis/activities/conferences/translationframes>.

6. BITRA: 2 hits for publications with either "gatekeeping" (Vuorinen 1997) or "gatekeeper" (Davidson 2009) in the title. LIDOC: 4 hits (Monnier 1995; Vuorinen 1997; Sarangi and Roberts 1999; Davidson 2009).

7. Official project title: Community Interpreting und Kommunikationsqualität im Sozial- und Gesundheitswesen. This subproject was part of a larger project (Migrationsforschung am Zentrum für Kulturwissenschaft der Universität Graz) funded under a specific Research Programme maintained by the Research Department of the Provincial Government of the Austrian province of Styria (Zukunftsfonds des Landes Steiermark) with a project sum of 150.000 in total.

8. Institutions involved: Department of Pedagogy, Graz University; Department of Translation Studies, Graz University; SAT Social Architecture Team; ZEBRA Interkulturelles Beratungs- und Therapiezentrum.

9. This objective could be implemented in both institutions: the project team initiated (or conducted) specific measures as a result of the project outcome in both institutions (for example, workshops, translation of brochures).

10. No preferences regarding language combinations were voiced before the start of the project. Recordings were done by staff members themselves. The predominance of Chechen in the corpus is arbitrary but reflects the language situation in the participating institutions (and other Austrian institutions though Chechnyians also often have to resort to Russian and/or Russian-speaking interpreters). 
11. "Uncommon" language combinations (when it comes to IS) entail specific problems regarding transcription, translation and interpretation of foreign-language passages. These challenges cannot be presented here in detail, some aspects have been addressed in Pöllabauer (2009).

12. The concept of "translation culture" was introduced into TS by Prunč $(1997 ; 2000)$ and can be defined as the diachronically and diaculturally variable set of norms, conventions and expectations framing the behaviour of all interactants in the field of translation (Prunč 2000: 59).

13. EULITA: European Legal Interpreters and Translators Association (Last updated: 16 June 2011) Visited on 22 June 2011, <http://eulita.eu/home>.

14. ELC/CEL European Language Council. Visited 22 June 2011, <http://www.celelc.org/>.

15. Transcripts are read from left to right (time frame of utterances) and vertically (overlapping talk). Transcription conventions: (xxx): inaudible; (word): suspected wording; ((nods)): comment; ((3s)): pauses of 3 seconds or longer; /: restarts. The upper line of the transcript shows the speakers' original utterances (which sometimes also show instances of code-switching). The English text in italics is my translation of the original utterances. IR: institutional representative; Int: interpreter; C: client.

16. Line 20 - IR: informal German dialect; Int: code-switching between German dialect, Turkish, and German again. Line 21 - Int: German; C: Code-switiching between German and Turkish.

\section{REFERENCES}

Almansi, Daniela (2010): Gate-Keeping and Gate-Crashing in Nonsense and Translation. The Case of fiddle-de-dee: Do You Know Languages? CTIS Occasional Papers. 6:41-53.

Angelelli, Claudia V. (2004): Revisiting the Interpreter's Role. A Study of Conference, Court, and Medical Interpreters in Canada, Mexico, and the United States. Amsterdam/Philadelphia: John Benjamins.

BAHADIr, Şebnem (2010): Dolmetschinszenierungen. Kulturen, Identitäten, Akteure. Berlin: SAXA.

BAKER, Nicholas G. (1981): Social Work through an Interpreter. Social Work. 26(5):391-397.

Barzilai-Nahon, Karine (2008): Gatekeeping: A Critical Review. ARIST Annual Review of Information Science and Technology. Visited on 24 February 2012, <http://www.mendeley. com/research/gatekeeping-critical-review/>.

BARZILAI-NAHON, Karine (2009): Gatekeeping: A Critical Review. Annual Review of Information Science and Technology. 43(1):1-79.

Blair, David, Campbell, Stuart, Chesher, Terry, et al. (1990): A Prototype Term Bank of Health and Social Welfare Terms. Terminologie et Traduction (T\&T). 3(1):69-82.

Cambridge, Jan (2005): The Public Service Interpreter's Face: Rising to the Challenge of Expressing Powerful Emotion for Others. Revista Canaria de Estudios Ingleses. 51:141-157.

Cerzniewski, Alexandra (2007): Kommunikation mit MigrantInnen in Berliner Jugendämtern. Eine Studie zum Bedarf an Sprach- und KulturmittlerInnen. In: Theda BordE and NielsJens Albrecht, eds. Innovative Konzepte für Integration und Partizipation. Bedarfsanalyse zur interkulturellen Kommunikation in Institutionen und für Modelle neuer Arbeitsfelder. Frankfurt am Main: IKO Verlag, 76-96.

Chang, Kuo (Last updated: 2004) Gatekeeping: An Integrative Conceptual Model. Paper presented at the annual meeting of the International Communication Association (New Orleans, May 27, 2004). Visited on 24 February 2012 , <http://citation.allacademic.com//meta/p_mla_apa_ research_citation/1/1/2/3/5/pages112359/p112359-1.php>.

Corsellis, Ann (2003): Formación de los proveedores de servicios públicos para trabajar con intérpretes y traductores. Habilidades y competencias interculturales. In: Carmen VALERO GARCÉs, ed. Traducción e interpretación en los servicios públicos. Contextualización, actualidad y futuro. Alcalá de Henares/Granada: Universidad de Alcalá de Henares y Comares, 71-89.

DAVIDSON, Brad (2009): The interpreter as institutional gatekeeper. The social-linguistic role of interpreters in Spanish-English medical discourse. In: Mona BAKER, ed. Translation Studies: Critical Concepts in Linguistics. 3. London/New York: Routledge, 216-243. 
Debevc-Moroz, Helena (1995): Les services de traduction dans une municipalité multiculturelle et plurilingue. In: Marie-Christine Aubin, ed. Perspectives d'avenir en traduction - Future Trends in Translation. Proceedings of the Conference on the Occasion of the $10^{\text {th }}$ Anniversary of the École de traduction du Collège universitaire de Saint-Boniface, September-October, 1994. Winnipeg: Collège universitaire de Saint-Boniface, 173-180.

El Madkouri, Maataoui (2006): La traducción e interpretación en los servicios sociales: los condicionantes administrativo-culturales. In: Pilar Blanco Garciá and Pilar Martino Alba, eds. Traducción y multiculturalidad. Proceedings of the XI Encuentros complutenses en torno a la traducción, November 2005. Instituto Universitario de Lenguas Modernas y Traducción, Universidad Complutense de Madrid. Madrid: Universidad Complutense, 145156.

Emmel, Horst (1992): Sozialberatung für Ausländer in Hamburg: vom Dolmetscherdienst zur Sozialarbeit. Standpunkt: sozial. 2:68-71.

ERICKson, Frederick and Shultz, Jeffrey (1982): The Counselor as Gatekeeper. Social Interaction in Interviews. London/New York: Academic Press.

Ertl, Anita and Pöllabauer, Sonja (2010): Training (Medical) Interpreters - the Key to Good Practice. MedInt: A Joint European Training Perspective. JoSTrans (The Journal of Specialised Translation). 14:165-193. Visited 22 June 2011, <http://www.jostrans.org/issue14/art_ ertl.php>.

FujII, Akio (1988): News Translation in Japan. Meta. 33(1):32-37.

Gaitanides, Stefan (1997): Verstehen, Verständigung, Vertrautheit. Chancen und Schwierigkeiten der Kommunikation im Beratungsalltag mit MigrantInnen unter dem Aspekt von sprachlich/kultureller Vertrautheit und Fremdheit. Sozialmagazin. 22(1):52-56.

Glasser, Irene (1983): Guidelines for Using an Interpreter in Social Work. Child Welfare. 62(5):468-470.

Grbić, Nadja and Pöllabauer, Sonja (2008a): To count or not to count: Scientometrics as a methodological tool for investigating research on translation and interpreting. TIS Translation and Interpreting Studies. 3(1/2):87-146.

Grbić, Nadja and Pöllabauer, Sonja (2008b): Counting what counts. Research on community interpreting in German-speaking countries - A scientometric study. Target. 20(2):297-332.

Gross-Dinter, Ursula (2009): Konferenzdolmetschen und Community Interpreting: Schritte zu einer Partnerschaft. In: Wolfram Baur, Sylvia Kalina, Jutta Witzel, et al., eds. Übersetzen in die Zukunft. Herausforderungen der Globalisierung für Dolmetscher und Übersetzer. Schriften des BDÜ. Vol. 32. Berlin: Bundesverband der Dolmetscher und Übersetzer (BDÜ), 354-362.

Hale, Sandra Beatriz (2007): Community Interpreting. Basingstoke/New York: Palgrave Macmillan.

Jensen, John B. and Camayd-Freixas, Erik (2004): Interpreting for Social Services: A New Federally-Mandated Field. The ATA Chronicle. 33(5):26-30.

KADRIĆ, Mira (2009): Dolmetschen bei Gericht. Erwartungen, Anforderungen, Kompetenzen. Wien: facultas.wuv Universitäts.

Kuкovetz, Brigitte and Sprung, Annette (2009): Bedarfserhebung und Analyse bezüglich der Kommunikationssituation zwischen MitarbeiterInnen des Bürgerbüro Kapfenbergs und des Wohnungsamtes Graz und KundInnen mit Migrationshintergrund. Graz: unpublished research report.

Kurtz, Norman R. (1968): Gatekeepers: Agents in Acculturation. Rural Sociology. 33(1):64-70.

LANNoy, Katrien and VAN GUCHT, Jan (2006): Babel rebuilt: a survey of social welfare institutions and interpreting and translation services in Flanders. In: Anthony Рум, Zuzana Jettmarová and Miriam Shlesinger, eds. Sociocultural Aspects of Translating and Interpreting. Amsterdam/Philadelphia: Benjamins, 199-208.

Lewin, Kurt (1947): Frontiers in Group Dynamics. Human Relations. 1(2):5-41.

LewIN, Kurt (1951): Field theory in social science: Selected theoretical papers. New York: Harper. Lin, Margrith A. and Mutter, Karl (1998): Interkulturelle Beratungsarbeit mit DolmetscherInnen. Psychologie \& Erziehung P\&E. 2:33-44. 
Lu, Yang (2007): The human in human information acquisition: Understanding gatekeeping and proposing new directions in scholarship. Library and Information Science Research. 29:103123.

Manyoni, Thabo (1999): Interpreting and translation services for local government in South Africa. In: Mabel Erasmus, Mathibela Lebohang, Erik Hertog, et al., eds. Liaison Interpreting in the Community. Hatfield: van Schaik, 123-129.

Mason, Ian (2009): Role, Positioning and Discourse in Face-to-Face Interpreting. In: Raquel de Pedro Ricoy, Christine Wilson and Isabelle Perez, eds. Interpreting and Translating in Public Service Settings. Policy, Practice, Pedagogy. Manchester/Kinderhook: St. Jerome, 52-73.

Metoyer-Durand, Cheryl (1991): Information-Seeking Behavior of Gatekeepers in Ethnolinguistic Communities: Overview of a Taxonomy. Library and Information Science Research. 13:319-346.

Meyer, Bernd (2009): Deutschkenntnisse von MigrantInnen und ihre Konsequenzen für das Dolmetschen im Krankenhaus. In: Dörte Andres and Sonja Pöllabauer, eds. Spürst $d u$ wie der Bauch rauf-runter? Fachdolmetschen im medizinischen Bereich/Is everything all topsy turvy in your tummy? Medical Interpreting. InterPartes - Studien zur Dolmetschwissenschaft. Vol. 5. München: Meidenbauer, 139-157.

Monnier, Michel Acatl (1995): The Hidden Part of the Asylum Seekers' Interviews in Geneva, Switzerland: Some Observations about the Socio-Political Construction of Interviews between Gatekeepers and the Powerless. Journal of Refugee Studies. 8(3):305-325.

Monti, Silvia (2010): Screen Translation as Gateway and Gate-Keeping in Ae Fond Kiss. CTIS Occasional Papers. 5:24-48.

Ozolins, Uldis (2000): Communication Needs and Interpreting in Multilingual Settings: The International Spectrum of Response. In: Roda P. RoberTs, Sylvana CARr, Diana Abraham, et al., eds. The Critical Link 2: Interpreters in the Community. Papers from the $2^{\text {nd }}$ International Conference on Interpreting in Legal, Health, and Social Service Settings (Vancouver, BC, Canada, 19-23 May, 1998). Amsterdam/Philadelphia: John Benjamins, 21-34.

Ozolins, Uldis (2010): Factors that determine the provision of Public Service Interpreting: comparative perspectives on government motivation and language service implementation. JoSTrans (The Journal of Specialised Translation). 14:194-215. Visited 22 June 2011, <http:// www.jostrans.org/issue14/art_ozolins.php>.

PöchHacker, Franz (2000a): Dolmetschen: Konzeptuelle Grundlagen und deskriptive Untersuchungen. Studien zur Translation. Vol. 7. Tübingen: Stauffenburg.

PöchHACKer, Franz (2000b): Dolmetschen - ein Kinderspiel? Eine klinische Fallstudie. TEXTconTEXT. 14(2):153-180.

PöchHACKer, Franz (2004): Introducing Interpreting Studies. London: Routledge.

PöchHACKer, Franz (2007): Giving access - or not: A developing-country perspective on healthcare interpreting. In: Franz PöchнаскеR, Arnt Lykke JakobSen and Inger M. Mees, eds. Interpreting Studies and Beyond. A tribute to Miriam Shlesinger. Copenhagen Studies in Language. Vol. 35. Frederiksberg: Samfundslitteratur, 121-137.

Pöllabauer, Sonja (2009): Community Interpreting und Kommunikationsqualität im Sozial- und Gesundheitswesen. Forschungsbericht: Analyse gedolmetschter Gespräche am Bürgerbüro Kapfenberg und dem Wohnungsamt Graz. Graz: Unpublished research report.

Pöllabauer, Sonja (2010): Community Interpreting bei Ämtern der Sozialverwaltung: Auf der Suche nach Verständigung. In: Nadja Grbić, Gernot Hebenstreit, Gisella VorderoberMeIER, et al., eds. Translationskultur revisited. Festschrift für Erich Prunc. Tübingen: Stauffenburg, 353-375.

Pöllabauer, Sonja and Zettelbauer, Heidrun (2009): Endbericht. Forschungsschwerpunkt Migration am Zentrum für Kulturwissenschaft. Graz: Unpublished report.

PrunČ, Erich (1997): Translationskultur (Versuch einer konstruktiven Kritik des translatorischen Handelns). TEXTconTEXT. 11[Neuer Folge 1](2):99-127. 
PRUnč, Erich (2000): Vom Translationsbiedermeier zur Cyber-translation. TEXTconTEXT. 14[Neuer Folge 4]:3-74.

Rennie, Sandra (1998): Interpreting and Access to Public Services: A Text Book for Public Service Interpreters and Trainers. Bradford: Sequals.

Roe, Donald, L. and Roe, Connie E. (1991): The Third Party: Using Interpreters for the Deaf in Counseling Situations. Journal of Mental Health Counselling. 13(1):91-105.

Rudvin, Mette (2005): Power behind Discourse and Power in Discourse in Community Interpreting: The Effect of Institutional Power Asymmetry on Interpreter Strategies. Revista Canaria de Estudios Ingleses. 51:159-179.

Rudvin, Mette (2006): The cultural turn in Community Interpreting. A brief analysis of epistemological developments in Community Interpreting literature in the light of paradigm changes in the humanities. Linguistica Antverpiensia New Series. 5:21-41.

SARANGI, Srikant and Roberts, Celia (1999): The dynamics of interactional and institutional orders in work-related settings. In: Srikant SARAngi and Celia Roberts, eds. Talk, Work and Institutional Order. Discourse in Medical, Mediation and Management Settings. Berlin/ New York: Mouton de Gruyter, 1-57.

Sarangi, Srikant and Slembrouck, Stefaan (1996): Language, Bureaucracy and Social Control. Longman: Infinity Publishing.

Shackman, Jane (1984): The Right to be Understood. A Handbook on Working With, Employing and Training Community Interpreters. Cambridge: Cambridge Extension College.

Shoemaker, Pamela J. (1991): Gatekeeping. Newbury Park: Sage.

Shoemaker, Pamela J. and Vos, Tim P. (2009): Gatekeeping Theory. New York/London: Routledge.

TIĞLI, Nursevim (2007): Bilinguale Beratung im Jugendamt, Selbstverständlichkeit oder Luxus? In: Theda Borde and Niels-Jens Albrecht, eds. Innovative Konzepte für Integration und Partizipation. Bedarfsanalyse zur interkulturellen Kommunikation in Institutionen und für Modelle neuer Arbeitsfelder. Frankfurt am Main: IKO Verlag, 192-218.

Tipton, Rebecca (2008): Interpreter Neutrality and the Structure/Agency Distinction. In: Carmen VALERO-GarCÉs, ed. Investigación y práctica en traducción e interpretación en los servicios públicos - desafíos y alianzas. Research and practice in public service interpreting and translation - challenges and alliances. Obras Colectivas, Humanidades. Vol. 10. Alcalá de Henares: Universidad de Alcalá de Henares, 183-197.

Uebelacker, Johanna (2007): Sprach- und Kulturmittlung aus der Sicht des Personals eines Berliner Bezirksamtes. In: Theda Borde and Niels-Jens Albrecht, eds. Innovative Konzepte für Integration und Partizipation. Bedarfsanalyse zur interkulturellen Kommunikation in Institutionen und für Modelle neuer Arbeitsfelder. Frankfurt am Main: IKO Verlag, 42-73.

Vuorinen, Erkka (1997): News translation as gatekeeping. In: Mary SNeLL-Hornby, Zuzana Jettmarová and Klaus KaIndL, eds. Translation as Intercultural Communication. Selected Papers From the EST Congress - Prague 1995. Amsterdam/Philadelphia: John Benjamins, 161-172.

WADENSJö, Cecilia (1998): Interpreting as Interaction. London/New York: Longman.

Wedam, Uta (2009): Sprachkultur - Plädoyer für das Dolmetschen im therapeutischen Kontext. In: Dörte Andres and Sonja Pöllabauer, eds. Spürst Du, wie der Bauch rauf-runter? Fachdolmetschen im Gesundheitsbereich. Is everything all topsy turvy in your tummy? Health Care Interpreting. InterPartes - Studien zur Dolmetschwissenschaft. Vol. 5. München: Meidenbauer, 181-195.

Westley, Bruce and MacLean, Malcolm (1957): A Conceptual Model for Communications Research. Journalism Quarterly. 34:31-38.

White, David M. (1950): The 'Gate Keeper': A Case Study in the Selection of News. Journalism Quarterly. 27:383-390.

Wilson, Erica M. (1996): Needs of deaf people in counselling: experiences of clients and counsellors. Deaf Worlds. 12:2-10. 
Wouters, Eveline (1999): City of Antwerp: Municipal Language Mediation Service. In: Mabel Erasmus, Mathibela, Lebohang, Erik Hertog, et al., eds. Liaison Interpreting in the Community. Hatfield: van Schaik, 130-134.

Yallop, Colin (1992): Terms in Social Welfare: Terminological and Linguistic Perspectives. In: Bruno DE Bessé, ed. Phraséologie et Terminologie en Traduction et en Interprétation. Numéro spécial de Terminologie et Traduction. Proceedings of the Colloque Anniversaire de l'ÉTI (Geneva, October 1991). Luxembourg: C.E.C., 447-456. 